\title{
KARAKTERISTIK KONSELOR ISLAMI \\ (KAJIAN EMPIRIS NILAI-NILAI PENDIDIKAN KARAKTER SYEKH MUHAMMAD ARSYAD AL-BANJARI)
}

\author{
Khairullah, Akhmad Rizkhi Ridhani, Aminah \\ Universitas Islam Kalimantan Muhammad Arsyad Al-Banjari Banjarmasin \\ E-mail: rizkhi.ridhani@gmail.com/ 085391881999
}

\begin{abstract}
ABSTRAK
Konselor sebagai tenaga profesional tentunya harus mampu memberikan pelayanan secara optimal, sistematis, objektif, logis, serta berkelanjutan kepada setiap individu agar individu tersebut dapat berkembang optimal sesuai dengan perkembangannya masing-masing. Indonesia merupakan mayoritas pendudukannya Islam tentunya merupakan tatantangan tersendiri bagi seorang konselor dalam memberikan layanan. Maka oleh sebab itu perlu dikaji bagaimana karakteristik konselor islami. Penelitian ini bertujuan untuk mengkaji nilai-nilai pendidikan karakter Syekh Muhammad Arsyad Al-Banjari sebagai dasar untuk mengetahui bagaimana bentuk karakteristik konselor islami. Metodologi yang digunakan ialah kualitatif dengan desain etnografi realis, yang dimana data diperoleh melalui orang ketiga, kemudian dari pada itu melaporkan secara objektif tentang informasi yang dipelajari dari partisipan di lapangan. Intrumen utama dalam penelitian ini ialah wawanacara. Hasil dari penelitian ini ialah terdapatnya nilai-nilai pendidikan karakter Syekh Muhammad Arsyad Al-Banjari dari kisah-kisah beliau semasa hidup. Selain dari pada itu tersusunya karakteristik konselor islami berdasarkan kajian empris dari nilai pendidikan karakter Syekh Muhammad Arsyad Al-Banjari.
\end{abstract}

Kata Kunci: Karakteristik Konselor Islami, Syekh Muhammad Arsyad Al-Banjari

\section{ABSTRACT}

Counselors as professionals must certainly be able to provide services optimally, systematically, objectively, logically, and sustainably to each individual so that individuals can develop optimally in accordance with their respective developments. Indonesia is the majority of its occupation Islam is certainly a separate challenge for a counselor in providing services. Therefore, it is necessary to examine the characteristics of Islamic counselors. This study aims to examine the character education values of Syekh Muhammad Arsyad Al-Banjari as a basis for knowing how the characteristics of Islamic counselors are. The methodology used is qualitative with a realist ethnographic design, in which data is obtained through a third person, then from that it reports objectively on information learned from participants in the field. The main instrument in this study is wawanacara. The results of this study are the existence of the character education values of Syekh Muhammad Arsyad Al-Banjari from the stories of him during his lifetime. Apart from that the characteristics of Islamic counselors are based on empirical studies of the character education values of Syekh Muhammad Arsyad Al-Banjari

Keywords: Characteristics of Islamic Counselors, Shekh Muhammad Arsyad Al-Banjari.

Dipublikasikan Oleh :

UPT Publikasi dan Pengelolaan Jurnal

Universitas Islam Kalimantan Muhammad Arsyad Al-Banjari Banjarmasin 


\section{PENDAHULUAN}

Indonesia merupakan suatu negera yang memiliki ragam budaya, budaya bangsa indonesia ini ialah seluruh kebudayaan nasionalataupun kebudayaan lokal yang tersebar di seluruh wilayah Indonesia. Selain memiliki ragam budaya Indonesia juga terkenal dengan ragam agamanya, yang dimana Islam merupakan agama mayoritas dari penduduk di Indonesia. Walaupun Indonesia memiliki ragam budaya dan agama namun tetap satu, dan hal ini tergambarkan melalui filosofi Bhineka Tunggal Ika (berbeda-beda namun tetap satu).

Indonesia sebagai bangsa yang memiliki penduduk Islam terbesar di dunia, yang dimana pada tahun 2010 terdapat 87,18\% atau 207 juta jiwa dari 238 jta jiwa penduduk Indonesia beragam Islam (wikipedia, 2018). Islam mulai masuk ke Indonesia menurut sumber wikipedia ensiklopedia bebas dapat dilihat dari fokus diskusi yakni; (1) tempat asal kedatanganya, (2) pembawanya, dan (3) waktu kedatanganya. Namun terlepas dari itu semua, jelas bahwasanya Islam memang merupakan agama masyoritas dari penduduk di Indonesia. Sebagai negara yang mayoritas berpenduduk Islam, tentunya terdapat banyak ulama-ulama karismatik yang tersebar diseluruh nusantara, tak terkecuali di Kalimantan khususnya Kalimantan Selatan.

Syekh Muhammad Arsyad Al-Banjari merupakan ulama terkenal asal dari Kalimantan Selatan tepatnya di kampung Lok Gabang Kecamatan Astambul Kabupaten Banjar (Daudi). Sebagai ulama panutan yang penuh karismatik, beliau semasa hidupnya banyak melahirkan kitab-kitabuntuk kemaslahatan umat, salah satu yang paling fenomenal ialah kitab Sabilal Muhtadin (Halidi, 2016). Selain itu produktif menulis kitab, beliau juga turut berkontribusi dalam mensyiarkan agama islam khususnya di wilayah Kalimantan Selatan melalui metode dakwah. Menurut Ariani(2010) terdapat 3 (tigas) metode dakwah yang digunakan oleh Syekh Muhammad Arsyad Al-Banjari yakni; (1) dakwah bilLisan, (2) dakwah bil-Hal, dan (3) dakwah bilKitabah. Tiga metode ini kalau kita kaitakan dengan dunia pendidikan di Indoensia saat ini tentulah sangat sesuai, dikerenakan metode ini memang sering digunakan oleh tenaga pendidik dilembaga pendidikan formal, non formal, dan informal dalam proses belajar dan mengajar.

Pendidikan di Indonesia didasarkan kepada Undang-Undang Nomor 20 Tahun 2003 tentang Sistem Pendidikan Nasional Indonesia yang dimana tujuan utamanya ialah mencerdaskan kehidupan bangsa, sehingga memiliki kekuatan spritual keagaman, pengendalian diri, kepribadian, kecerdasan, akhlak mulia, serta segala sesuai yang beguna bagi diri individu, nusa, dan bangsa. Kemudian dari pada itu dalam penyelenggaraan pendidikan ini terdapat pendidik yang dimana menurut sikdiknas salah satunya ialah guru. Guru merupakan tenaga pendidik yang dimana merupakan seorang individu yang memiliki suatu keahlian dibidangnya masing-masing. Seperti guru mata pelajaran ipa, ips, bahasa, matematika, dan lain sebagainya, selain itu pula terdapat guru bimbingan dan konseling yang ikut berperan dalam mencerdaskan kehidupan bangsa dengan ranah kerjanya yakni mewujudkan perkembangan optimal peserta didik.

Bimbingan dan Konseling merupakan layanan yang terintegral dalam dunia pendidikan, dan berfokus kepada perkembangan peserta didik. Permendikbud Nomor 111 Tahun 2014 Tentang Bimbingan dan Konseling Pada Pendidikan Dasar dan Pendidikan Menengah menjelaskan bahwa layanan bimbingan dan konseling merupakan suatu layanan yang sistematis, objektif, logis, dan berkelanjutan serta terprogram yang dilakukan oleh konselor atau guru bimbingan dan konseling untuk memfasilitasi perkembangan peserta didik/konseli untuk mencapai kemandirian dalam kehidupannya.

Guru Bimbingan dan Konseling/ konselor sebagai tenaga profesional yang merupakan seorang tenaga pendidik dengan kualifikasi pendidikan sarjana pendidikan (S.Pd) bidang bimbingan dan konseling, serta telah menempuh pendidikan profesi konselor (Kons) seperti yang tertuang dalam Permendiknas Nomor 27 Tahun 2008 Tentang Standar Kualifikasi dan Kompetensi Konselor, memiliki ekpektasi kinerja yakni selalu tergerak oleh motif altruistik, sikap empati yang peka, menghormati perbedaan, serta mengutamakan kepentingan individu yang dilayani. Kemudian dari pada itu pula selain terdapat kualifikasi akademik dalam guru bimbingan dan konseling/ konselor, juga terdapat kompetensi yang harus dipenuhi oleh seorang konselor yakni mencakup kompetensi; (1) pedagogik, (2) kepribadian, (3) sosial, serta (4) profesional.

Indonesia yang memiliki penduduk mayoritas Islam seperti yang telah dikemukan sebelumnya, tentu menjadi tantangan tersendiri bagi seorang guru bimbingan dan konseling/ konselor ketika melayani individu yang meminta bantuan, maka oleh sebab itu penting bagi kita untuk mengetahui bagaimana karakteristik konselor islami dengan mengkaji nilainilai pendidikan karakter salah satu ulama karismatik asal Kalimantan Selatan yakni Syekh Muhammad Arsyad Al-Banjari.

\section{METODE}

Sesuai dengan fokus penelitian yakni kajian empiris nilai-nilai pendidikan karakter Syekh Muhammad Arsyad Al-Banjari sebagai dasar untuk menetapkan karakteristik konselor islami. Maka 
metodelogi yang digunakan ialah kualitatif dengan desain etnografi realis. Menurut Creswell (2015:936) etnografi realis adalah pendekatan popular yang digunakan oleh para antropolog budaya, penjelasan objektif tentang situasi yang biasanya ditulis dalam padangan orang ketiga.Kemudian dari pada itu melaporkan secara objektif tentang informasi yang dipelajari dari partisipan di lapangan.

Pada penelitian ini padangan orang ketiga yang dimaksud ialah murid Syekh Muhammad Arsyad AlBanjari, yang dimana orang tersebut tahu persis tentang ajaran yang diajarkan oleh Syekh Muhammad Arsyad Al-Banjari, sehingga orang tersebut dapat memberikan informasi langsung kepada peneliti berkenaan dengan nilai-nilai pendidikan karakter Syekh Muhammad Arsyad Al-Banjari sebagai bahan untuk mengkaji dan menetapkan karakteristik konselor islami.

Instrumen pengumpul data, jenis data, subyek, tujuan, dan analisis yang digunakan peneliti yakni dapat dilihat pada tabel 1 sebagai berikut:

Tabel 1. Instrumen Pengumpul Data, Jenis Data, Subyek, Tujuan, dan Analisis Yang Digunakan Peneliti

\begin{tabular}{cclll}
\hline Instrumen & Jenis Data & \multicolumn{1}{c}{ Subyek } & \multicolumn{1}{c}{ Tujuan } & Analisis \\
\hline Pedoman & Kualitatif & Murid Syekh Muhammad & Mengetahui kondisi & Deskriptif \\
Wawancara & & Arsyad Al-Banjari, Juriat & faktual nilai-nilai & Kualitatif \\
& & Syekh Muhammad Arsyad & pendidikan karakter Syekh & \\
& & Al-Banjari & Muhammad Arsyad Al- & \\
& & Banjari & \\
\hline
\end{tabular}

\section{HASIL DAN PEMBAHASAN}

Adapun hasil yang diperoleh berdasarkan pada wawanacara yang dilakukan kepada subyek yang menjadi sumber dalam perolehan data pada kajian empiris nilai-nilai pendidikan karakter Syekh Muhammad Arsyad Al-Banjari yakni meliputi :

\section{Kondisi Faktual Nilai-Nilai Pendidikan Karakter Syekh Muhammad Arsyad Al-Banjari}

Nilai-nilai pendidikan karakter Syech Muhammad Asryad Al-Banjari ini dapat tergambarkan melaluipengalan kisah-kisah beliau semasa hidup, yang dimana dalam kisah-kisah beliau ini dapat ditarik suatu nilai pendidikan yang beliau ajarkan kepada murid-murid beliau dan masyarakat sekitardimasa beliau masih hidup. Adapun nilai-nilai pendidikan karakter Syekh Muhammad Arsyad Al-Banjari tersebut dapat tergambar sebagai berikut :

\section{Kelahiran Yang Dinanti-Nanti}

Pada malam kamis jam 3 dinihari hampir subuh, sedang embun dingin turun mengusap bumi, dan bulan pun sedang purnama tepat nya 13 malam bulan Syafar tahun $112 \mathrm{H}$ bertepatan dengan tahun 1710 M. lahirlah seorang bayi putra dari pasangan Abdullah dan Siti Aminah di desa Log Gabang, yang diberi nama Muhammad Arsyad. Semakin hari bayi tersebut tumbuh dan berkembangan hingga menjadi anak-anak, dan diusianya 8 tahun dirinya sudah terlihat berbeda dari anak-anak seusianya tersebut. Muhammad Arsyad merupakan orang yang taat terhadap kedua orangnya, ia sangat ta'zim dan patuh. Kemudian dari pada itu pula ditengah-tengah pergaulannya dengan teman sebayanya Muhammad Arsyad terkenal dengan kejujurannya, bukan sebagai teman yang menggunting dalam lipatan, begitu pula kepribadiannya dihiasai dengan tingkah laku yang

Dipublikasikan Oleh :

UPT Publikasi dan Pengelolaan Jurnal

Universitas Islam Kalimantan Muhammad Arsyad Al-Banjari Banjarmasin sopan dan santun.Sampai ketika saat itu baginda Raja Sultan Tahlilillah tertarik akan bakat dan pembawaan anak dari pasangan Abdullah dan Siti Aminah tersebut hingga membawa anak tersebut untuk menetap di istana.

\section{Belajar Ke Tanah Suci Mekkah}

Syekh Muhammad Arsyad Al-Banjari merupakan seorang yang cerdas dan berbeda dengan anak pada umumnya, ketika beliau tinggal di istana beliau sangat begitu disayangi oleh baginda raja seolah-olah seperti anak kandung sendiri, begitu pula kasih sayang yang berikan oleh orang-orang di istana kepada beliau.Hal ini karena beliau memiliki kepribadian yang baik, suatu kebijaksanaan menjaga amal perbuatan dengan dihiasi akhlak yang sangat menarik, sehingga wajarlah seluruh penghuni istana menyayangi dan menghormatinya.Ketika beliau tinggal di istana baginda raja Sultan Tahlilillahmemerintahkan kepada salah seorang guru untuk belajar mengaji al-Qur'an, ternyata beliau Syekh Muhammad Arsyad Al-Banjari memiliki kecerdasan yang luar biasa, daya tangkapnya sangat kuat, segala pelajaran yang diajarkan diterimanya dengan mudah, serta hafalanya yang sangat luar biasa sehingga terus melekat dalam ingatan hatinya dan pikirannya. Sultan Tahlilillah sangat gembira meliat perkembangan belau yang sangat begitu hebat, sampai kepada sang sultan berjanji untuk menugaskannya belajar ke Mekkah guna menambah pengetahuan agama yang lebih mendalam, dengan dibiayai oleh kerajaan. Kemudian lebih dari pada itu singkat cerita sebelum beliau diberangkatkan ke Mekkah beliau dinikahkan dengan seorang wanita yang taat penghuni istana bernama Bajut disaat umur beliau 30 tahun. 
Lebih kurang 30 tahun lamanya beliau memperdalam ilmu agama di Mekkah dan Madinah, banyak ilmu yang diterimanya, bukan saja ilmu agama dan bahasa arab, namun lebih dari pada itu ilmu-ilmu pengetahuan alampun beliau pelajari. Diantara guru beliau yang terkenal ialah Syekh Athaillah bin Ahmad Al-Azhari, Syekh Islam Imamul Haramain Al-Alimul Allamah Muhammad bin Sulaiman Al-Kurdi, serta dibidang tasawuf beliau belajar dengan seorang guru besar, ahli sufi di kota Madinah bersama Sayyidul Arif Billah Syekh Muhammad bin Abd Karim As Samman Al-Madani, dengan guru inilah beliau belajar bersamasama murid yang lain asal Indonesia yakni Syekh Abd Samad Al-Palembani, dan berkenan masing-masing melaksanakan khalwat di bawah pimpinan guru besar tersebut, dimana setelah selesai mereka berdua mendapat ijazah dengan kedudukan sebagai Khalifah.

\section{Membetulkan Arah Kiblat}

Rindu kampung halaman yang sudah 35 tahun ditinggalkan, 30 tahun di Mekkah dan 5 tahun di Madinah, kini kembali menggugah jiwa perasaan Syekh Muhammad Arsyad Al-Banjari. Kemudian dari pada itu terlintas dipikiran beliau dikala itu betapa berat tugas dan kewajiban yang akan beliau hadapi untuk melaksanakan dakwah islam, bila sudah tiba di tanah air. Namun semua itu harus beliau hadapi dengan semangat juang yang tinggi, sekalipun terkadang berbagai rupa peristiwa berat harus dihadapi dan dilalui.

Pada saat perjalanan puang menuju kampung halaman, baliau bersama dua sahabat laianya yakni Abd Rahman Mesri dan Abd Wahab Bugissinggah di Betawi (Jakarta).Kedatangan beliau tersebut disambut hangat oleh para tokoh masyarakat, ulama, serta pejabat waktu itu. Pada kesempatan ini pula beliau menghampiri beberapa masjid dan salah satunya yang dibenarkan arah kiblatnya yakni masjid jembatan lima, dan disana dituliskan memori bahwa "arah kiblat masjid ini diputar ke kanan sebanyak 25 derajat oleh Syekh Muhammad Arsyad Al-Banjari” pada tanggal 4 Syafar 1186 H/ 7 Mei 1771 M.

\section{Menyelesaikan Masalah Pelik}

Setibanya dikampung halaman bersama sahabat dan juga merupakan menantu pertamnaya pada bulan Ramadhan, Tahun 1186 H/ Desember $1772 \mathrm{M}$, tiba-tiba menghadapi suatu masalah yang rumti, dimana ketika beliau masih di Mekkah mendengar bahwa puteri beliau sudahlah deasa maka atas kesepakatan bersama beliau nikahkan puteri beliau yang bernama Syarifah itu dengan Syekh Abd Wahab Bugis atas dasar wali Mujbir, sedangkan saat itu Sultan di Martapura pada menikahkan pula
Syarifah tersebut dengan seorang dari kampung Melayu, bernama Usman atas dasar Wali hakim, dan telah memperoleh momongan seorang laki-laki yang diberi nama Muhammad As'ad.

Menurut hukum Islam bentuk nikah keduanya sah menurut tempatnya masing-masing, namun bagi Syekh Muhammad Asryad Al-Banjari saat itu hal ini perlu ditinjau kembali dan ditetapkan berdasarkan hukum Islam, siapakah yang tetap kesahannya dalam pernikahan anaknya tersebut. maka setelah meneliti secara seksama dengan memperhitungkan waktu anatara Mekkah dan Martapura, maka berdasarkan keahlianya di bidang ilmu Falak, didaptkan suatu kepastian bahwa nikah yang di Mekkah yang tetap kesahnnya, dengan demikian ikatan perkawinan antara Usman dan Syarifah setelah diketahui yang tetap kesahannya yang di Mekkah, maka terputuslah karenanya (difasakh), dengan dilandasi keimanan yang kuat dan tunduk terhadap hukum-hukum Islam yang berlaku, maka putusan tersebut diputuskan atas dasar keikhlasan melaksanakanya, maka masingmasing pihak saat itu dapat menerimanya dengan baik, dan ditetapkanlah suami dari anak beliau yakni Syarifah adalah Syekh Abd Wahab Bugis.

\section{Membuka Perkampungan Baru dan Membuat Irigasi}

Kedatangan Syekh Muhammad Arsyad AlBanjari dari Mekkah disambut dengan penuh kembiraan dan kehangatan, saat itu beliau sudah dianggap sebagai "bubuhan" yakni raja (kaum bangsawan) sehingga beliau saat itu mendapat perlakukan yang sama seperti bangsawan lainnya yakni mendapatkan "tanah lungguh", yang dimana tanah terbut berhak beliau garap dan dijadikan perkampungan. Saat ini daerah tersebut disebut "kampung dalam pagar", dan di wilayah ini beliau mendirikan tempat-tempat pengajian sebagai putas pendidikan agama, serta beliau juga mendirikan tempat ibadah di wilayah tersebut.

Syekh Muhammad Asryad Al-Banjari saat itu juga mendapat sebutan "Tuan Haji Besar" dari penguas Belanda sewaktu beliau di Betawi, nama ini diabadikan dengan sebuah nama kampung. Selain membuka perkampungan sebagai pusat pendidikan agama, beliau juga memuka persawahan dan perkembangan di desa Kalampayan dekat dengan kampung Lok Gabang. Memperhatikan daerah yang buka persawahan dan perkebunan tersebut sangat luas dan belum dimanfaatkan dan digarap karena selalu digenangi air, maka untuk kepentingan masyarakat sekitar dalam meningkatkan penghasilan mereka, lalu beliau membuat salutan air $\pm 8 \mathrm{~km}$ yang dimana 
menurut kisah aliran sungai tersebut dibuat dengan mengoreskan tongkat beliau sehingga akhirnya menjadi anak sungai yang kemudian tempat tersebut dikenal dengan nama kamung "Sungai Tuan" dan menjadilah kampung tersebut subur serta berlimpah ruah hasil pertanian dan perkebunannya.

\section{Salah Satu Pelopor Islam}

Ketika Sultan Tahmidullah bin Sultan Tamjidilah melihat berbagai keberhasilan yang ditoreh oleh Syekh Muhammad Arsyad Al-Banjari dalam berdakwah dan menanamkan kesadaranakan ajaran agama Islam dan mencetak kader-kader dakwah yang berpusat di kampung dalam pagar. Maka Sultan tersebut berdiskusi dengan beliau dan lahirlah suatu lembaga huku yang bertugas untuk memberikan nasehat atau pendapat kepada kerajaan tentang hukum Islam yang diperlukan pada masa itu. Lembaga ini pertama kali dipimpin oleh cucu beliau Al-Alimul Allamah Muhammad As'ad putera dari Syerifah (dari suami bernama Usman) sebagai Mufti (ulama yang berwenang menginterprestasi suatu hal dan memberi fawa kepada umat) dan Al-Alimul Allamah $\mathrm{H}$. Abu Su'ud (dari isteri Syekh Muhamamad Asryad AlBanjari yang bernama Tuan Bidur) sebagai Qadhi (sorang hakim yang membuat keputusan berdasarkan syariat islam).

Maka untuk hal ini dapat dicatatan dalam sejarah perkembangan islam di Kalimantan Selatan, bahwa islam berkembang dan menyebarluas ajarannya atas keberhasilan Syekh Muhammad Arsyad AlBanjari, serta kebijaksanannya dalam menerapakan cara pendidikan islam.

\section{Berdakwah Secara Intensif}

Syekh Muhammad Arsyad Al-Banjari disamping mengjar dan mendidik anak, cucu, dan para murid (santri) yang berdatangan dari berbagai tempat dan daerah, beliau juga pergi berdakwah kepada seluruh lapisan masyarakat kala itu.Keberhasilan dakwah beliau ini dikarenakan dalam berdakwah beliau memiliki strategi, kepekaan, dan ketanggapan beliau terhadap situasi seitar, sehingga dakwah beliau benar-benar mengena bagi seluruh lapisan masyrakat tak terkecuali keluarga bangsawan. Adapun strategi yang digunakan oleh beliau yakni; (1) Menyatunya dengan kelompok subjek dakwah; (2) menggiatkan kaderisasi dan regenerasi juru dakwah dan ulama; (3) berusaha mewujudkan kesejahteraan hidup masyarakat; (4) mengikutsertakan pengaruh dan kekuasaan kerajaan. Kemudian dari pada itu dari segi metode yang bilau gunakan dimasa itu yakni; (1) metode dakwah bil-Lisan; (2) metode dakwah bil-Hal; dan (3) metode dakwah bil-Kitabah.

\section{Mengoptimalkan Potensi Diri}

Syekh Muhammad Arsyad Al-Banjari semasa hidupnya merupakan seorang individu yang karismatik serta produktif.Beliau menulis kitab-kitab Islam yang mencakup seluruh ajaran Islam dalam bahasa melayu. Adapun diantaranya kitab yang beliau tulis yakni; (1) Ushuluddin; (2) Luqthatul Ajlan; (3) Kitab Fara-idh; (4) Kitabun Nikah; (5) Tuhfaturraghibin; (6) Qaulul Mukhtashar; (7) Ilmu Falak; (8) Kanzul Ma'rifah; (9) Mushaful Qur'an lengkap $30 \mathrm{Juz}$; (10) Qira-at Ibnu Katsir; (11) Qira-at Warasy, dan yang paling fenomenal ialah (12) Kitab Sabilah Muhtadien.

\section{Pembahasan Berkenaan dengan Kondisi Faktual Nilai-Nilai Pendidikan Karakter Syech Muhammad Arsyad Al-Banjari}

Berdasarkan pada kajian empris nilai-nilai pendidikan karakter yang terdapat pada penggalan-penggalan kisah Syekh Muhammad Arsyad Al-Banjari semasa hidupnya tersebut maka dapat dianalisis bahwa terdapat 18 nilai pendidikan karakter. Hal tersebut dapat dilihat dari tabel 2 .

Pembahasan Berkenaan dengan Karakteristik Konselor Islam Berdasarkan Kajian Empiris NilaiNilai Pendidikan Karakter Syekh Muhammad Arsyad Al-Banjar

Pembahasan berkenaan dengan telaah kondisi faktual nilai-nilai pendidikan karakter Syekh Muhmmad Arsyad Al-Banjari yang teruangkap melalui kisah-kisah beliau tersebut. Maka kita menyadari bahwasanya beliau benar-benar orang yang penuh karismatik dan bersahaja. Berdasarkan hal tersebut dapat dirumuskan seperti apa karakteristik seorang konselor islami dengan beracuan pada nilainilai pendidikan karakter Syekh Muhammad Arsyad Al-Banjari, yakni sebagai berikut pada gambar 1 dan tabel 3 . 
Tabel 2 Kondisi Faktual Nilai-Nilai Pendidikan Karakter Syekh Muhammad Arsyad Al-Banjari

\begin{tabular}{|c|c|c|c|}
\hline No & $\begin{array}{c}\text { Kisah Syekh Muhammad } \\
\text { Arsyad Al-Banjari Semasa } \\
\text { Hidup (112-1227 H/ 1710- } \\
1812 \mathrm{M})\end{array}$ & $\begin{array}{c}\text { Inti Sari Kisah Perjalanan } \\
\text { Hidup Syekh Muhammad } \\
\text { Arsyad Al-Banjari (112-1227 H/ } \\
\text { 1710-1812 M) }\end{array}$ & $\begin{array}{l}\text { Nilai Pendidikan Karakter Syekh } \\
\text { Muhammad Arsyad Al-Banjari }\end{array}$ \\
\hline 1 & $\begin{array}{l}\text { Kelahiran Yang Dinanti- } \\
\text { Nanti }\end{array}$ & $\begin{array}{ll}\text { - } & \text { Seorang yang ta'zim dan patu } \\
\text { - } & \text { Seorang yang jujur } \\
\text { - } & \text { Berperilaku sopan dan santun } \\
\text { - } & \text { Memiliki bakat }\end{array}$ & $\begin{array}{ll}\text { - } & \text { Jujur } \\
\text { - } & \text { Akhlak mulia } \\
\text { - } & \text { Taat kepada orang yang lebih } \\
& \text { tua }\end{array}$ \\
\hline 2 & $\begin{array}{l}\text { Belajar Ke Tanah Suci } \\
\text { Mekkah }\end{array}$ & $\begin{array}{l}\text { - } \quad \text { Seorang yang cerdas } \\
\text { - } \quad \text { Seorang yang taat beragama } \\
\text { - } \quad \text { Memiliki rasa ingin tahu yang } \\
\text { tinggi }\end{array}$ & $\begin{array}{ll}- & \text { Rasa ingin tahu } \\
\text { - } & \text { Religius }\end{array}$ \\
\hline 3 & Membetulkan Arah Kiblat & $\begin{array}{ll}\text { - } & \text { Memiliki rasa cinta tanah air } \\
\text { - } & \text { Memiliki rasa tanggung jawab }\end{array}$ & $\begin{array}{ll}\text { - } & \text { Cinta tanah air } \\
\text { - } & \text { Bertanggung jawab }\end{array}$ \\
\hline 4 & $\begin{array}{l}\text { Menyelesaikan } \\
\text { Pelik }\end{array}$ & $\begin{array}{l}\text { - Seorang yang demokratis } \\
\text { - Memiliki pengetahuan yang } \\
\text { luas }\end{array}$ & $\begin{array}{l}\text { - Demokratis } \\
\text { - Pengetahuan yang luas }\end{array}$ \\
\hline 5 & $\begin{array}{l}\text { Membuka Perkampungan } \\
\text { Baru dan Membuat Irigasi }\end{array}$ & $\begin{array}{l}\text { - } \text { Memiliki kreatif yang tinggi } \\
\text { - } \text { Memiliki rasa peduli } \\
\text { lingkungan } \\
\text { - } \\
\text { Memiliki rasa kepekaan sosial } \\
\text { yang tinggi }\end{array}$ & $\begin{array}{ll}\text { - } & \text { Kreatif } \\
\text { - } & \text { Peduli lingkungan } \\
- & \text { Peduli sosial }\end{array}$ \\
\hline 6 & Salah Satu Pelopor Islam & $\begin{array}{l}\text { - } \quad \text { Seorang pekerja keras } \\
\text { - } \quad \text { Seorang yang Islam yang taat } \\
\text { - } \quad \text { Seorang yang bijaksana }\end{array}$ & $\begin{array}{ll}\text { - } & \text { Kerja keras } \\
\text { - } & \text { Bijaksana } \\
\text { - } & \text { Semangat kebangsaan } \\
\text { - } & \text { Menghargai prestasi }\end{array}$ \\
\hline 7 & Berda'wah Secara Intensif & 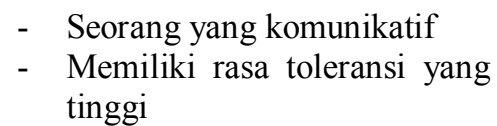 & $\begin{array}{ll}\text { - } & \text { Bersahabat dan komunikatif } \\
\text { - } & \text { Toleransi } \\
\text { - } & \text { Cinta damai }\end{array}$ \\
\hline 8 & $\begin{array}{l}\text { Mengoptimalkan } \\
\text { Diri }\end{array}$ & 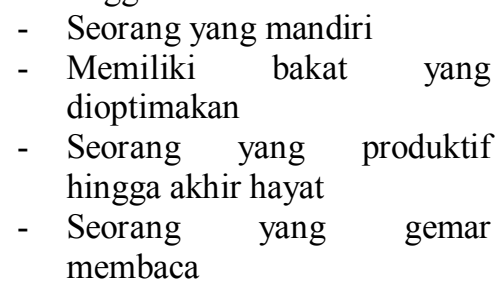 & $\begin{array}{ll}\text { - } & \text { Mandiri } \\
\text { - } & \text { Sadar akan kemampuan diri } \\
\text { - } & \text { Disiplin dan produktif } \\
\text { - } & \text { Gemar membaca }\end{array}$ \\
\hline
\end{tabular}

Gambar 1 Alur Kajian dalam Menelaah Karakteristik Konselor Islam Berdasarkan Kajian Empiris Nilai-Nilai Pendidikan Karakter Syekh Muhammad Arsyad Al-Banjar

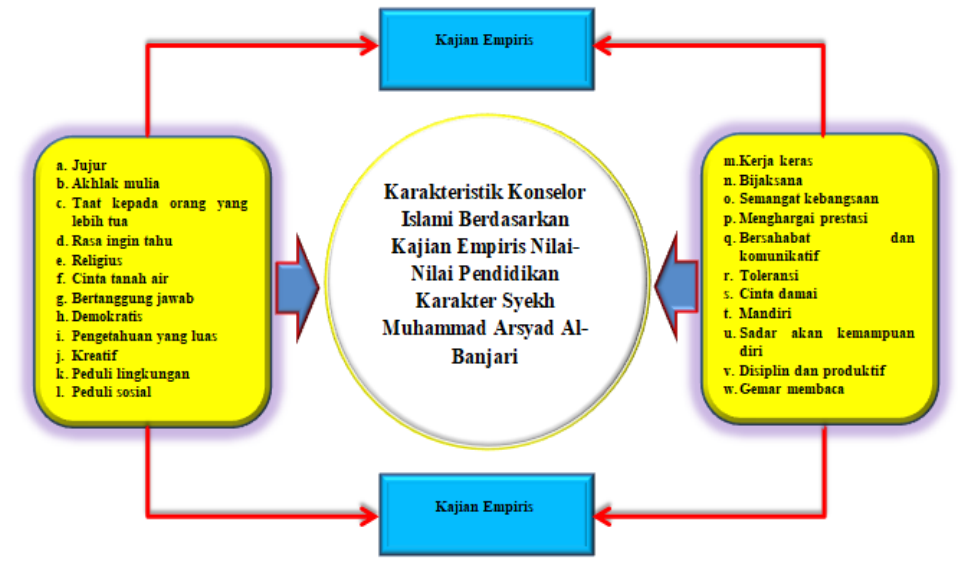

Dipublikasikan Oleh :

UPT Publikasi dan Pengelolaan Jurnal

Universitas Islam Kalimantan Muhammad Arsyad Al-Banjari Banjarmasin 
Tabel 3 Karakteristik Konselor Islami Berdasarkan Kajian Empiris Nilai-Nilai Pendidikan Karakter Syekh Muhammad Arsyad Al-Banjari

\begin{tabular}{|c|c|c|c|}
\hline $\begin{array}{l}\text { Kriteria } \\
\text { Konselor Islami }\end{array}$ & $\begin{array}{l}\text { Karakter Konselor } \\
\text { Konvensional }\end{array}$ & $\begin{array}{l}\text { Nilai Pendidikan } \\
\text { Karakter Syekh } \\
\text { Muhammad } \\
\text { Arsyad Al-Banjari }\end{array}$ & $\begin{array}{l}\text { Karakteristik Konselor Islami } \\
\text { Berdasarkan Kajian Empiris Nilai- } \\
\text { Nilai Pendidikan Karakter Syekh } \\
\text { Muhammad Arsyad Al-Banjari }\end{array}$ \\
\hline & 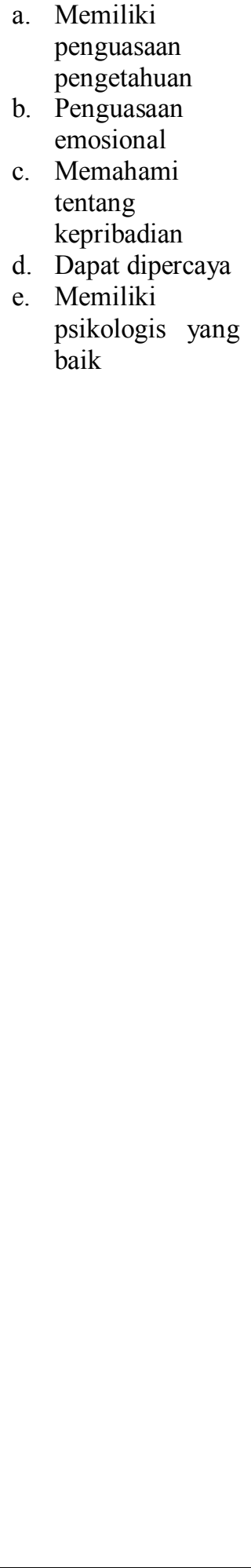 & $\begin{array}{l}\text { a. Jujur } \\
\text { b. Akhlak mulia } \\
\text { c. Taat kepada } \\
\text { orang yang lebih } \\
\text { tua } \\
\text { d. Rasa ingin tahu } \\
\text { e. Religius } \\
\text { f. Cinta tanah air } \\
\text { g. Bertanggung } \\
\text { jawab } \\
\text { h. Demokratis } \\
\text { i. Pengetahuan } \\
\text { yang luas } \\
\text { j. Kreatif } \\
\text { k. Peduli } \\
\text { lingkungan } \\
\text { 1. Peduli sosial } \\
\text { m. Kerja keras } \\
\text { n. Bijaksana } \\
\text { o. Semangat } \\
\text { kebangsaan } \\
\text { p. Menghargai } \\
\text { prestasi } \\
\text { q. Bersahabat dan } \\
\text { komunikatif } \\
\text { r. Toleransi } \\
\text { s. Cinta damai } \\
\text { t. Mandiri } \\
\text { u. Sadar } \\
\text { vemampuan diri } \\
\text { v. Disiplin } \\
\text { produktif } \\
\text { w. Gemar membaca }\end{array}$ & 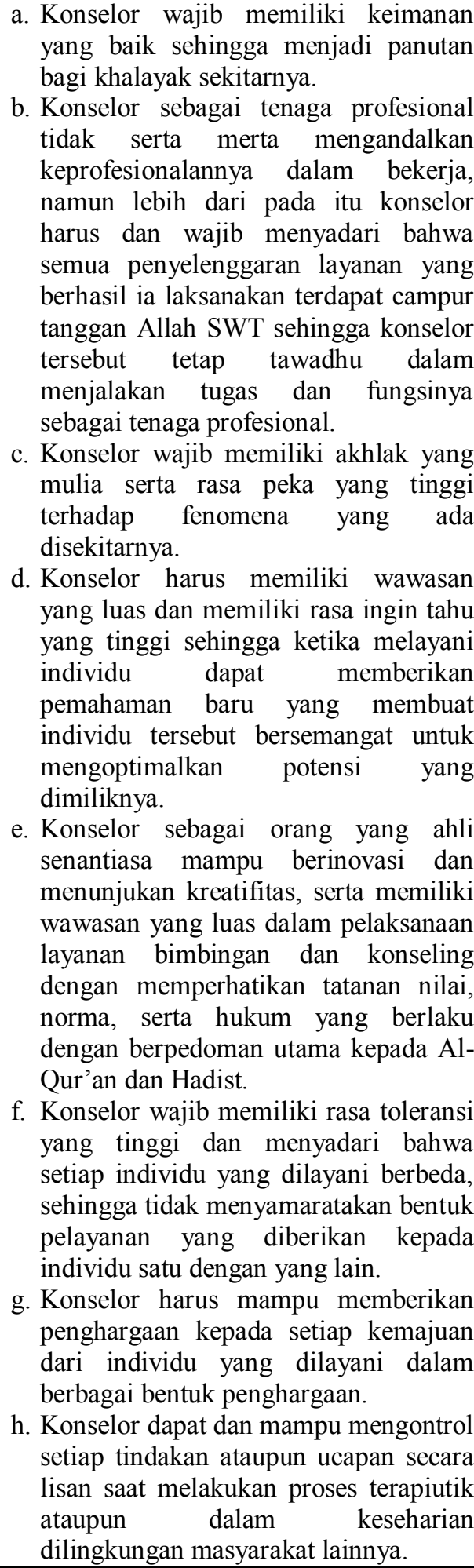 \\
\hline
\end{tabular}

Dipublikasikan Oleh :

UPT Publikasi dan Pengelolaan Jurnal

Universitas Islam Kalimantan Muhammad Arsyad Al-Banjari Banjarmasin 
i. Konselor dapat menjalin bekerjasama yang baik kepada tenaga profesional lainnya dengan mengutamakan rasa tanggung jawab.

j. Konselor dalam menjalankan layanan terapiutik ini mampu menjaga kerahasiaan yang diutarakan konseli sehingga konselor tersebut benar-benar menjaga kepercayaan konseli terhadap dirinya, dalam hal ini konselor benarbenar amanah.

k. Konselor harus bijaksana dalam bertindak dan berperilaku sehingga individu yang dilayani jiwanya damai dan tentram

\section{PENUTUP}

Berdasarkan hasil dan pembahasan yang telah dikemukan maka dapat disimpulkan bahwa: (a) Syekh Muhammad Arsyad Al-Banjari merupakan seorang ulama besar asal Kalimantan Selatan yang penuh karismatik dan hidup pada 112-1227 H/ 1710-1812 M. Beliau juga merupakan salah satu ulama yang ikut serta dalam penyebaran agama Islam khususnya di wilayah Kalimantan Selatan pada abad ke 18 dan 19 M. Beliau Syekh Muhammad Arsyad Al-Banjari merupakan ulama panutan bagi umat Islam dari dahulu hingga saat ini; (b) Terdapat suatu nilai pendidikan karakter yang dapat diambil dari kisahkisah Syekh Muhammad Arsyad Al-Banjari semasa hidupnya; (c) Tebentuknya karakteristik konselor islami berdasarkan kajian empiris nilai-nilai pendidikan karakter Syekh Muhammad Arsyad AlBanjari.

\section{REFERENSI}

Ariani, Anita. (2010). Gerakan Pemurnian Islam Syekh Muhammad Arsyad Al-Banjari Di Kalimantan. Jurnal Al-Fikr, 14 (3).

Creswell, John. (2015). Riset Pendidikan (Perencanaan, Pelaksanaan, dan Evaluasi Riset Kualitatif dan Kuantitatif. Yogyakarta: Pustaka Pelajar.

Daudi, Abu. Manaqib Syekh Muhammad Arsyad AlBanjari. Martapura : Kalimantan Selatan.

Halidi, Yusuf. (2016). Ulama Besar Kalimantan Syekh Muhammad Arsyad Al-Banjari (cetakan ke-4). Martapura: Kalimantan Selatan.

Peraturan Menteri Pendidikan dan Kebudayaan Indonesia Nomor 111 Tahun 2014 Tentang Bimbingan dan Konseling Pada Pendidikan Dasar dan Pendidikan Menengah.

Peraturan Menteri Pendidikan Nasional Indonesia Nomor 27 Tahun 2008 Tentang Standar Kualifikasi dan Kompetensi Konselor.
Undang-Undang Nomor 20 Tahun 2003 Tentang Sistem Pendidikan Nasional Indonesia.

Wikipedia. Islam Di Indonesia. https://id.wikipedia.org/wiki/Islam_di_Indonesia. Diunduh 6 September 2018.

Dipublikasikan Oleh :

UPT Publikasi dan Pengelolaan Jurnal

Universitas Islam Kalimantan Muhammad Arsyad Al-Banjari Banjarmasin 